\title{
AN EXAMINATION OF THE RELATIONSHIP BETWEEN SUPPLY CHAIN MANAGEMENT PRACTICES AND BUSINESS PERFORMANCE: A CASE ANALYSIS OF A PASSENGER RAIL COMPANY
}

\author{
C.J. Fourie ${ }^{1 *}$ \& 0. Chimusoro $^{1 \#}$
}

\section{ARTICLE INFO}

\section{Article details}

Submitted by authors 22 Nov 2017

Accepted for publication $10 \mathrm{Jul} 2018$

Available online $\quad 31$ Aug 2018

\section{Contact details}

* Corresponding author cjf@sun.ac.za

Author affiliations

1 PRASA Chair for Maintenance Management, Department of Industrial Engineering, University of Stellenbosch, South Africa

\# $\quad$ Author was enrolled for a PhD in the Department of Industrial Engineering, University of Stellenbosch, South Africa

DOI

http://dx.doi.org/10.7166/29-2-1876

\section{ABSTRACT}

The lack of maintenance engineering performance is one of the main causes of poor service delivery. In a passenger rail company, maintenance engineering performance is measured using several parameters, which include the ability of the organisation to upgrade and replace its fleet, the availability of spares, skills availability, information flow, and information technology. The aim of this study was to investigate the situation in a passenger rail company in South Africa in order to determine whether its supply chain management practices would influence business performance and, in this case, maintenance engineering performance. After a chi-square test was done, the results showed that there was a positive influence by supply chain management practices on business performance.

\section{OPSOMMING}

'n Tekort aan instandhoudingsingenieurswese prestasie is een van die hoof oorsake van swak dienslewering. Instandhoudingsingeneurswese prestasie in ' $n$ passasiers spoormaatskapy word gemeet aan die hand van verskeie parameters wat insluit die vermoë van die organisasie om sy vloot op te gradeer en te vervang, die beskikbaarheid van spaar onderdele, die beskikbaarheid van vaardighede, die vloei van inligting, en informasie tegnologie. Die doel van hierdie studie was om die omstandighede in 'n passasiers spoormaatskappy in Suid Afrika te ondersoek met die doel om te bepaal of voorsieningskettingbestuur praktyke 'n invloed sal uitoefen op besigheidsprestasie, meer spesifiek, instandhoudings ingenieurswese prestasie. 'n Chi-kwadraat toets het getoon dat voorsieningskettingbestuur praktyke wel 'n positiewe invloed op besigheidsprestasie het.

\section{INTRODUCTION}

Research has shown that most organisations are not adequately prepared to manage supply chain risks, and a failure to respond quickly to a disruption can be very costly [1]. Despite the abundance of such research on supply chain management in recent years, its impact on maintenance engineering performance and its impact in a dynamic environment such as a passenger rail transport organisation's performance is not as plentiful. So there is still a lot of work to be done in creating or designing a robust generic supply chain model to evaluate and predict the impact of the supply chain on maintenance engineering performance and management practices in a service industry such as passenger rail transport.

The lack of maintenance engineering performance is one of the main causes of poor service delivery. Thus, in a passenger rail transport operation, maintenance engineering performance is measured using several parameters, which include the ability of the organisation to upgrade and replace its fleet, the availability of spares, skills availability, information flow, and information technology (IT). 
The aim of this study was to investigate the situation in a passenger rail company in South Africa to determine whether its supply chain management practices would influence business performance and, in this case, maintenance engineering performance.

\section{RESEARCH QUESTION AND HYPOTHESIS}

The research question that gave rise to this study was whether there is any linkage between supply chain management practices and maintenance engineering performance in a passenger rail environment. From the research question, the hypothesis for the study was formulated.

Du Plooy-Cilliers, Davis \& Bezuidenhout [2] state that hypotheses are statements or proposed explanations made on the basis of limited evidence as a starting point for further investigation. They can also take the form of statements of proposed alternative 'facts', or states of affairs, or tentative statements that can assist to establish whether certain relationships exist between dependent and independent variables. Furthermore, it can be a process by which hypotheses follow principles of deductive logic - that is, drawing conclusions about particular knowledge of the general [3]. Based on this study's research problem and research questions, it can be postulated that a positive correlation exists between supply chain management practices and maintenance engineering performance (business performance).

\section{LITERATURE REVIEW}

The international railway industry standard governs the upkeep of train sets, and covers an organisation's complete management requirements, such as governance processes, service delivery processes, and support [4]. A train is a complex system that includes thousands of parts and components that are derived from three main complementary technological sub-sectors: electromechanical, electronics, and mechanical [5]. According to Sharma, Banga \& Agarwal et al. [6], there are two basic forms of maintenance practices: (i) breakdown maintenance, which happens due to unpredictable failure or gradual wear and tear of the parts, and (ii) preventive maintenance, which happens on the basis of prediction or periodical checking. Both forms are explored in this study. Furthermore, Patton [7] defines maintenance as a set of activities that aim to ensure that the buildings, plants, and machinery of an organisation are kept in such a condition that they can continue to carry out their required function satisfactorily. Sharma et al. [6] allude to forecasting requirements for spare parts and to using the internet or intranet to order them as needed. Patton [7], in line with Sharma et al. [6], adds that maintenance engineering is concerned with understanding the maintenance function, prioritising maintenance work, and deciding on objectives, forecasting, maintenance planning, maintenance scheduling, and organising maintenance work (labour allocation). In broader terms, the targets of maintenance management are to preserve the asset function, avoid the consequences of the failure of the asset, improve plant availability and efficiency, reduce the maintenance cost, ensure the optimum use of staff and, last but not least, ensure that spare parts are available when and where required.

Overhead electrified railways continue to be affected adversely by dewirement incidents, as stated by Keen [8]. He adds that damage to overhead line equipment (OHLE) in particular can cause severe disruption to railway operations, with significant costs being incurred as a result of each dewirement incident. These costs are in the form of penalties incurred and the cost of repairing damaged equipment. The causes of dewirement are not yet fully understood. Each seems to be caused by a unique and complex set of elemental conditions, including OHLE and pantograph anomalies, local topographic and meteorological conditions, train speed, and geographic features. Damage is believed to occur, however, when these conditions combine to drive the dynamic interaction of pantograph and OHLE beyond their performance 'envelope'. Of late, further disruptions have, of course, been caused by cable theft and vandalism, which occur totally at random.

'Maintenance management' refers to the coordinating, controlling, planning, executing, and monitoring of the correct maintenance activities of any kind in a manufacturing or service operation [7]. This, of course, refers to planned and preventive maintenance with a known pattern, and can be achieved through an effective supply chain management system. However, when breakdown and unplanned maintenance have to be carried out, the supply chain has to be adaptive and robust enough to be able to handle the disruptions caused by the breakdowns. It is therefore essential that 
the linkage between the supply chain and the business performance (maintenance) in a passenger rail environment be studied and analysed.

\section{METHODOLOGY}

The passenger rail company in question is the main service provider for passenger transport in South Africa. There are various maintenance depots throughout South Africa, with the main depots being in Gauteng, Cape Town, and Durban. To obtain information on the link between maintenance activities and the supply chain, a list of questions was selected with the help of the managers of the company. These questions were then compiled in questionnaires that were distributed at Wits Rolling Stock in Johannesburg, and at Salt River Rolling Stock in Cape Town. When using this method of obtaining information, it is vital that all ethical considerations be observed. For this reason, the authors endeavored to maintain integrity and so to ensure confidence in the research that was conducted. Ethical clearance was applied for and given by the appropriate research division, with strict conditions for adherence to all research ethics.

The respondents consisted of senior managers, managers, and supervisors. In Johannesburg, twenty questionnaires were hand-delivered and e-mailed, and four weeks were given for their completion and return. Of these, fifteen respondents completed and returned the questionnaires. For Cape Town, e-mail questionnaires were used. Eleven were sent, and five respondents completed and returned them.

\section{FINDINGS}

\subsection{Analysis of management aspects}

One critical investigation area involved aspects relating to management. Ten questions were asked: the presence of a known supply chain management (SCM) policy, known SCM goals, senior management commitment to SCM policies, management's involvement in SCM culture, management training in SCM, management adherence to SCM concepts, communication of SCM responsibilities, coordination of SCM processes, community's knowledge of SCM goals, and resources available for SCM improvement.

\subsubsection{SCM policy}

In respect of a known SCM policy, the responses are presented in Table 1.

Table 1: Our company has a known SCM policy

\begin{tabular}{|c|c|c|c|c|c|}
\hline & Response & Frequency & Per cent & Valid per cent & $\begin{array}{c}\text { Cumulative per } \\
\text { cent }\end{array}$ \\
\hline \multirow[t]{6}{*}{ Valid } & Strongly disagree & 1 & 5.0 & 5.0 & 5.0 \\
\hline & Somewhat disagree & 2 & 10.0 & 10.0 & 15.0 \\
\hline & Uncertain & 5 & 25.0 & 25.0 & 40.0 \\
\hline & Somewhat agree & 7 & 35.0 & 35.0 & 75.0 \\
\hline & Strongly agree & 5 & 25.0 & 25.0 & 100.0 \\
\hline & Total & 20 & 100.0 & 100.0 & \\
\hline
\end{tabular}

Table 1 shows that a high number of respondents agreed that there is an SCM policy in the organisation $(60 \%)$; three disagreed $(15 \%)$; while five were non-committal $(25 \%)$. It is worrying that 25 per cent of managers would be uncertain about the availability of a known SCM policy. After all, managers are the custodians of company policies, and ensure that the rest of the employees adhere to the policies.

\subsubsection{SCM goals}

The next question sought to establish whether the employees know what the SCM goals are. The responses are shown in Table 2. 
Table 2: Employees know our SCM goals

\begin{tabular}{|c|c|c|c|c|c|}
\hline & Response & Frequency & Per cent & Valid per cent & $\begin{array}{c}\text { Cumulative per } \\
\text { cent }\end{array}$ \\
\hline \multirow[t]{6}{*}{ Valid } & Strongly disagree & 4 & 20.0 & 20.0 & 20.0 \\
\hline & Somewhat disagree & 4 & 20.0 & 20.0 & 40.0 \\
\hline & Uncertain & 5 & 25.0 & 25.0 & 65.0 \\
\hline & Somewhat agree & 3 & 15.0 & 15.0 & 80.0 \\
\hline & Strongly agree & 4 & 20.0 & 20.0 & 100.0 \\
\hline & Total & 20 & 100.0 & 100.0 & \\
\hline
\end{tabular}

Table 2 shows that the respondents were balanced between the negative and the positive: five respondents were uncertain (25\%), eight disagreed (40\%), and seven agreed $(35 \%)$. These responses can be linked to the outcomes in Table 1, where some respondents were uncertain of the SCM policy. It may follow that, when the manager is unaware, the employees also lack knowledge.

\subsubsection{Senior management's commitment to SCM policies}

Senior management's commitment to SCM policies is critical for effective and efficient SCM. A question therefore asked whether senior management is committed to SCM. The responses in Table 3 illustrate the views of management.

Table 3: Senior management is committed to SCM

\begin{tabular}{|ll|c|c|c|c|}
\hline & & & & Cumulative per \\
cent
\end{tabular}

Table 3 shows a positive tilt, with 45 per cent positive, 35 per cent negative, and 20 per cent uncertain.

\subsubsection{Management's involvement in SCM culture}

Closely linked to commitment is the question whether management is visibly involved in developing an SCM culture. The responses to this question are shown in Table 4.

Table 4: Management is visibly involved in developing an SCM culture

\begin{tabular}{|c|c|c|c|c|c|}
\hline & Response & Frequency & Per cent & Valid per cent & $\begin{array}{c}\text { Cumulative per } \\
\text { cent }\end{array}$ \\
\hline \multirow[t]{6}{*}{ Valid } & Strongly disagree & 6 & 30.0 & 30.0 & 30.0 \\
\hline & Somewhat disagree & 2 & 10.0 & 10.0 & 40.0 \\
\hline & Uncertain & 3 & 15.0 & 15.0 & 55.0 \\
\hline & Somewhat agree & 5 & 25.0 & 25.0 & 80.0 \\
\hline & Strongly agree & 4 & 20.0 & 20.0 & 100.0 \\
\hline & Total & 20 & 100.0 & 100.0 & \\
\hline
\end{tabular}

Table 4 shows a balance of negative and positive responses, with 40 per cent negative, 45 per cent positive, and 15 per cent uncertain.

\subsubsection{Management training in SCM}

Training and development is important for best SCM practice. A question was therefore asked whether management is trained in SCM concepts. The responses are presented in Table 5. 
Table 5: Management is trained in SCM concepts

\begin{tabular}{|c|c|c|c|c|c|}
\hline & Response & Frequency & Per cent & Valid per cent & $\begin{array}{c}\text { Cumulative per } \\
\text { cent }\end{array}$ \\
\hline \multirow[t]{6}{*}{ Valid } & Strongly disagree & 3 & 15.0 & 15.0 & 15.0 \\
\hline & Somewhat disagree & 2 & 10.0 & 10.0 & 25.0 \\
\hline & Uncertain & 9 & 45.0 & 45.0 & 70.0 \\
\hline & Somewhat agree & 2 & 10.0 & 10.0 & 80.0 \\
\hline & Strongly agree & 4 & 20.0 & 20.0 & 100.0 \\
\hline & Total & 20 & 100.0 & 100.0 & \\
\hline
\end{tabular}

Table 5 shows that a high number of respondents were uncertain or negative about their being trained in SCM concepts: 25 per cent were negative, 45 per cent were uncertain, while only 30 per cent were positive. The lack of training of management in SCM processes is a worrying issue especially in a complex organisation, where expectations of service delivery to customers are high.

\subsubsection{Management adherence to SCM concepts}

A follow-up question on SCM concepts was to find out whether management itself adheres to SCM concepts. Table 6 shows the responses.

Table 6: Management practices SCM concepts

\begin{tabular}{|c|c|c|c|c|c|}
\hline \multicolumn{2}{|r|}{ Response } & Frequency & Per cent & Valid per cent & $\begin{array}{c}\text { Cumulative per } \\
\text { cent }\end{array}$ \\
\hline \multirow[t]{6}{*}{ Valid } & Strongly disagree & 2 & 10.0 & 10.0 & 10.0 \\
\hline & Somewhat disagree & 3 & 15.0 & 15.0 & 25.0 \\
\hline & Uncertain & 6 & 30.0 & 30.0 & 55.0 \\
\hline & Somewhat agree & 5 & 25.0 & 25.0 & 80.0 \\
\hline & Strongly agree & 4 & 20.0 & 20.0 & 100.0 \\
\hline & Total & 20 & 100.0 & 100.0 & \\
\hline
\end{tabular}

Table 6 shows that there is some support for the idea that management practises SCM concepts, with 45 per cent being positive, 30 per cent uncertain, and 25 per cent negative. The fact that management is more positive than negative could point to an organisation where managers selfteach SCM concepts. There is a disparity in how SCM is applied, and the outcomes are also different from manager to manager.

\subsubsection{Communication of SCM responsibilities}

The next question was whether SCM responsibilities were communicated to all employees. Communication would ensure that everyone knows their responsibilities and can therefore be held accountable. The responses to this question are shown in Table 7.

Table 7: SCM responsibilities have been clearly communicated to all employees

\begin{tabular}{|c|c|c|c|c|c|}
\hline & Response & Frequency & Per cent & Valid per cent & $\begin{array}{c}\text { Cumulative per } \\
\text { cent }\end{array}$ \\
\hline \multirow[t]{6}{*}{ Valid } & Strongly disagree & 5 & 25.0 & 25.0 & 25.0 \\
\hline & Somewhat disagree & 7 & 35.0 & 35.0 & 60.0 \\
\hline & Uncertain & 5 & 25.0 & 25.0 & 85.0 \\
\hline & Somewhat agree & 1 & 5.0 & 5.0 & 90.0 \\
\hline & Strongly agree & 2 & 10.0 & 10.0 & 100.0 \\
\hline & Total & 20 & 100.0 & 100.0 & \\
\hline
\end{tabular}

Table 7 shows that the SCM responsibilities have not been clearly articulated to all the employees. This follows from the results in Tables 5 and 6 that showed that managers are not trained in SCM concepts and that they could be self-teaching themselves. Of the respondents, 60 per cent were negative, 25 per cent uncertain, and 15 per cent positive. 


\subsubsection{Coordination of SCM processes}

Coordination of SCM processes is vital from the point of view of ensuring that the processes run smoothly. For this reason, it is important that SCM committees be in place to coordinate the activities. These committees integrate the departments and ensure that they work closely together for greater SCM efficiencies. This project sought to establish the extent of such coordination in the organisation. The findings are shown in Table 8.

Table 8: SCM committees coordinate between departments

\begin{tabular}{|c|c|c|c|c|c|}
\hline & Response & Frequency & Per cent & Valid per cent & $\begin{array}{c}\text { Cumulative per } \\
\text { cent }\end{array}$ \\
\hline \multirow[t]{6}{*}{ Valid } & Strongly disagree & 7 & 35.0 & 35.0 & 35.0 \\
\hline & Somewhat disagree & 3 & 15.0 & 15.0 & 50.0 \\
\hline & Uncertain & 4 & 20.0 & 20.0 & 70.0 \\
\hline & Somewhat agree & 5 & 25.0 & 25.0 & 95.0 \\
\hline & Strongly agree & 1 & 5.0 & 5.0 & 100.0 \\
\hline & Total & 20 & 100.0 & 100.0 & \\
\hline
\end{tabular}

Table 8 shows that a high number of respondents disagreed with the notion that SCM committees have been established to coordinate work between sections or departments. This is indicated by 50 per cent of respondents disagreeing, 20 per cent being uncertain, and 30 per cent being positive. This is worrying, because the onsite management team is not involved with the procurement of the spare parts they require.

\subsubsection{Community's knowledge of SCM goals}

The community is one of the organisation's key stakeholders. As a public entity, the public rail transport company being investigated is subject to public scrutiny; so transparency in SCM is critical. In this project, a question was asked whether the community knows what this company's SCM goals are. The results are shown in Table 9.

Table 9: The community knows our SCM goals

\begin{tabular}{|c|c|c|c|c|c|}
\hline \multicolumn{2}{|r|}{ Response } & Frequency & Per cent & Valid per cent & Cumulative per cent \\
\hline \multirow[t]{6}{*}{ Valid } & Strongly disagree & 6 & 30.0 & 30.0 & 30.0 \\
\hline & Somewhat disagree & 5 & 25.0 & 25.0 & 55.0 \\
\hline & Uncertain & 7 & 35.0 & 35.0 & 90.0 \\
\hline & Somewhat agree & 1 & 5.0 & 5.0 & 95.0 \\
\hline & Strongly agree & 1 & 5.0 & 5.0 & 100.0 \\
\hline & Total & 20 & 100.0 & 100.0 & \\
\hline
\end{tabular}

Table 9 shows that a relatively high number of respondents are negative about the community's understanding of the SCM goals, with 55 per cent being negative, 35 per cent uncertain, and 10 per cent positive.

\subsubsection{Resources available for SCM improvement}

The last question under the management aspects was whether sufficient resources are channelled and made available for SCM improvement. Resources would include human capital, in sufficient numbers and suitably qualified; finance for SCM processes; and employing modern technology. Table 10 contains the responses to this question.

Table 10: Adequate resources are provided for SCM improvements

\begin{tabular}{|c|c|c|c|c|c|}
\hline & Response & Frequency & Per cent & Valid per cent & $\begin{array}{c}\text { Cumulative per } \\
\text { cent }\end{array}$ \\
\hline \multirow[t]{6}{*}{ Valid } & Strongly disagree & 3 & 15.0 & 15.0 & 15.0 \\
\hline & Somewhat disagree & 7 & 35.0 & 35.0 & 50.0 \\
\hline & Uncertain & 5 & 25.0 & 25.0 & 75.0 \\
\hline & Somewhat agree & 3 & 15.0 & 15.0 & 90.0 \\
\hline & Strongly agree & 2 & 10.0 & 10.0 & 100.0 \\
\hline & Total & 20 & 100.0 & 100.0 & \\
\hline
\end{tabular}


Table 10 shows that managers feel that only limited resources are allocated to SCM processes, even though SCM is the major driver of maintenance engineering. This is indicated by 50 per cent replying in the negative, 25 per cent being uncertain, and 25 per cent being positive.

\subsection{Analysis of business performance in the last two years}

This aspect seeks to examine business performance in the past two years, specifically focusing on SCM or SCM-related parameters. The parameters covered include response time to customers, demonstration of improved SCM by support departments and suppliers, development of new products and services, use of independent companies to benchmark with competitors, and the level of customer complaints. The term 'customer' also refers to internal customers - in other words, departments within the organisation that depend on other departments for delivery.

\subsubsection{Response time}

Timeous responses to customer needs are important. Within the company being investigated, customer expectations are that trains arrive and depart on time, transport is delivered at an acceptable price, customer service is simplified, and trains are clean and safe. If these expectations are not satisfied, customers tend to abandon the service and choose other modes of transport. This project therefore sought to establish the extent to which response time to customers has improved. The findings are shown in Table 11.

Table 11: Our response time to customers has improved

\begin{tabular}{|c|c|c|c|c|c|}
\hline \multicolumn{2}{|c|}{ Response } & Frequency & Per cent & Valid per cent & $\begin{array}{c}\text { Cumulative per } \\
\text { cent }\end{array}$ \\
\hline \multirow[t]{6}{*}{ Valid } & Strongly disagree & 4 & 20.0 & 20.0 & 20.0 \\
\hline & Somewhat disagree & 7 & 35.0 & 35.0 & 55.0 \\
\hline & Uncertain & 5 & 25.0 & 25.0 & 80.0 \\
\hline & Somewhat agree & 2 & 10.0 & 10.0 & 90.0 \\
\hline & Strongly agree & 2 & 10.0 & 10.0 & 100.0 \\
\hline & Total & 20 & 100.0 & 100.0 & \\
\hline
\end{tabular}

Table 11 shows that views about improved customer response time lean strongly towards the negative, with 80 per cent being negative or uncertain, and only 20 per cent being positive. Response time has therefore not improved!

\subsubsection{Continuous improvement}

Continuous improvement is an integral part of business performance. This project sought to find out whether the organisation could demonstrate that there were improvements in SCM processes. The findings are given in Table 12.

Table 12: Improvement in SCM processes can be demonstrated

\begin{tabular}{|c|c|c|c|c|c|}
\hline \multicolumn{2}{|c|}{ Response } & Frequency & Per cent & Valid per cent & $\begin{array}{c}\text { Cumulative per } \\
\text { cent }\end{array}$ \\
\hline \multirow[t]{6}{*}{ Valid } & Strongly disagree & 7 & 35.0 & 35.0 & 35.0 \\
\hline & Somewhat disagree & 4 & 20.0 & 20.0 & 55.0 \\
\hline & Uncertain & 4 & 20.0 & 20.0 & 75.0 \\
\hline & Somewhat agree & 3 & 15.0 & 15.0 & 90.0 \\
\hline & Strongly agree & 2 & 10.0 & 10.0 & 100.0 \\
\hline & Total & 20 & 100.0 & 100.0 & \\
\hline
\end{tabular}

Table 12 shows that 55 per cent of the respondents disagreed that SCM processes have improved, while 20 per cent were uncertain, and 25 per cent agreed. Therefore it is evident that SCM processes have not improved.

\subsubsection{Inefficiencies in SCM}

Table 13 presents the results from the question whether other operators in the small business sector had collapsed due to inefficiencies in SCM in the organisation. 
Table 13: Other operators in the small business sector collapsed

\begin{tabular}{|c|c|c|c|c|c|}
\hline \multicolumn{2}{|c|}{ Response } & Frequency & Per cent & Valid per cent & $\begin{array}{c}\text { Cumulative per } \\
\text { cent }\end{array}$ \\
\hline \multirow[t]{5}{*}{ Valid } & Strongly disagree & 2 & 10.0 & 10.0 & 10.0 \\
\hline & Uncertain & 10 & 50.0 & 50.0 & 60.0 \\
\hline & Somewhat agree & 3 & 15.0 & 15.0 & 75.0 \\
\hline & Strongly agree & 5 & 25.0 & 25.0 & 100.0 \\
\hline & Total & 20 & 100.0 & 100.0 & \\
\hline
\end{tabular}

Table 13 shows that eight respondents (40\%) agreed that other operators in the small business sector had collapsed, while only two $(10 \%)$ disagreed with this. The remaining ten respondents $(50 \%)$ were uncertain.

\subsubsection{Support department's demonstration of SCM improvements}

A question asked whether improvements in SCM could be demonstrated by support departments as a follow-up to a question that asked whether support departments had defined SCM goals. The responses to this question are presented in Table 14.

Table 14: Improvements in SCM can be demonstrated by support departments

\begin{tabular}{|c|c|c|c|c|c|}
\hline \multicolumn{2}{|c|}{ Response } & Frequency & Per cent & Valid per cent & $\begin{array}{c}\text { Cumulative per } \\
\text { cent }\end{array}$ \\
\hline \multirow[t]{6}{*}{ Valid } & Strongly disagree & 3 & 15.0 & 15.0 & 15.0 \\
\hline & Somewhat disagree & 5 & 25.0 & 25.0 & 40.0 \\
\hline & Uncertain & 7 & 35.0 & 35.0 & 75.0 \\
\hline & Somewhat agree & 2 & 10.0 & 10.0 & 85.0 \\
\hline & Strongly agree & 3 & 15.0 & 15.0 & 100.0 \\
\hline & Total & 20 & 100.0 & 100.0 & \\
\hline
\end{tabular}

Table 14 shows that improvements in SCM by support departments cannot be positively demonstrated, with eight respondents disagreeing, seven being uncertain, while five agreed. This shows that 75 per cent were uncertain or negative.

\subsubsection{Suppliers' demonstration of SCM improvements}

Supplier improvements are critical to the success of internal processes of the organisation. Table 15 presents the results on whether improvements in SCM by suppliers can be demonstrated.

Table 15: Improvements in SCM by suppliers can be demonstrated

\begin{tabular}{|c|c|c|c|c|c|}
\hline \multicolumn{2}{|c|}{ Response } & Frequency & Per cent & Valid per cent & $\begin{array}{c}\text { Cumulative per } \\
\text { cent }\end{array}$ \\
\hline \multirow[t]{6}{*}{ Valid } & Strongly disagree & 2 & 10.0 & 10.0 & 10.0 \\
\hline & Somewhat disagree & 2 & 10.0 & 10.0 & 20.0 \\
\hline & Uncertain & 10 & 50.0 & 50.0 & 70.0 \\
\hline & Somewhat agree & 3 & 15.0 & 15.0 & 85.0 \\
\hline & Strongly agree & 3 & 15.0 & 15.0 & 100.0 \\
\hline & Total & 20 & 100.0 & 100.0 & \\
\hline
\end{tabular}

Table 15 shows that the responses were largely non-committal, with four respondents disagreeing, ten being uncertain, and six agreeing.

\subsubsection{Service delivery complaints}

Customers provide critical feedback for better service delivery. When there are many customer complaints, the company should prioritise addressing them. Table 16 shows whether there has been a decrease in customer complaints. 
Table 16: There has been a decrease in customers' complaints

\begin{tabular}{|c|c|c|c|c|c|}
\hline \multicolumn{2}{|c|}{ Response } & Frequency & Per cent & Valid per cent & $\begin{array}{c}\text { Cumulative per } \\
\text { cent }\end{array}$ \\
\hline \multirow[t]{6}{*}{ Valid } & Strongly disagree & 4 & 20.0 & 20.0 & 20.0 \\
\hline & Somewhat disagree & 9 & 45.0 & 45.0 & 65.0 \\
\hline & Uncertain & 3 & 15.0 & 15.0 & 80.0 \\
\hline & Somewhat agree & 1 & 5.0 & 5.0 & 85.0 \\
\hline & Strongly agree & 3 & 15.0 & 15.0 & 100.0 \\
\hline & Total & 20 & 100.0 & 100.0 & \\
\hline
\end{tabular}

Table 16 shows that there are negative responses on the number of customers' complaints, with thirteen respondents disagreeing, three being uncertain, and four agreeing. This shows that about 80 per cent are negative or uncertain.

\subsubsection{Development of new products and services}

The development of new products and services often keeps an organisation competitive. Table 17 presents the responses to the question whether the passenger rail company develops new products and services.

Table 17: We have developed several new products and services

\begin{tabular}{|c|c|c|c|c|c|}
\hline \multicolumn{2}{|c|}{ Response } & Frequency & Per cent & Valid per cent & $\begin{array}{c}\text { Cumulative per } \\
\text { cent }\end{array}$ \\
\hline \multirow[t]{6}{*}{ Valid } & Strongly disagree & 4 & 20.0 & 20.0 & 20.0 \\
\hline & Somewhat disagree & 6 & 30.0 & 30.0 & 50.0 \\
\hline & Uncertain & 6 & 30.0 & 30.0 & 80.0 \\
\hline & Somewhat agree & 2 & 10.0 & 10.0 & 90.0 \\
\hline & Strongly agree & 2 & 10.0 & 10.0 & 100.0 \\
\hline & Total & 20 & 100.0 & 100.0 & \\
\hline
\end{tabular}

Table 17 shows that there is a perception that only limited new products and services are developed, with ten respondents disagreeing with the question (50\%), six being uncertain $(30 \%)$, and four agreeing $(20 \%)$. These results may mean that there is not much communication to employees on innovation and creativity in the passenger railway company's product offering.

\subsubsection{Benchmarking against competitors}

A comparison of company performance with key competitors and best practice is critical for continuous improvement. This can be achieved by benchmarking a company's new product development against similar companies. The responses to this question are presented in Table 18.

Table 18: We use independent companies to compare our products and services with key benchmarks or competitors

\begin{tabular}{|c|c|c|c|c|c|}
\hline & Response & Frequency & Per cent & Valid per cent & $\begin{array}{c}\text { Cumulative per } \\
\text { cent }\end{array}$ \\
\hline \multirow[t]{6}{*}{ Valid } & Strongly disagree & 4 & 20.0 & 20.0 & 20.0 \\
\hline & Somewhat disagree & 2 & 10.0 & 10.0 & 30.0 \\
\hline & Uncertain & 10 & 50.0 & 50.0 & 80.0 \\
\hline & Somewhat agree & 2 & 10.0 & 10.0 & 90.0 \\
\hline & Strongly agree & 2 & 10.0 & 10.0 & 100.0 \\
\hline & Total & 20 & 100.0 & 100.0 & \\
\hline
\end{tabular}

Table 18 shows that the perception that products and services are being benchmarked against competitors is mainly negative or uncertain $(80 \%)$, with only 20 per cent agreeing. While there could be new product development because of benchmarking, it again shows that this is not communicated to middle management. 


\subsubsection{Improvement in business performance through SCM}

It is recognised that SCM enhances overall business performance. A question asked whether this relationship is recognised. The responses are given in Table 19.

Table 19: SCM plays a role in business performance

\begin{tabular}{|c|c|c|c|c|c|}
\hline \multicolumn{2}{|r|}{ Response } & Frequency & Per cent & Valid per cent & $\begin{array}{c}\text { Cumulative per } \\
\text { cent }\end{array}$ \\
\hline \multirow[t]{6}{*}{ Valid } & Strongly disagree & 1 & 5.0 & 5.0 & 5.0 \\
\hline & Somewhat disagree & 2 & 10.0 & 10.0 & 15.0 \\
\hline & Uncertain & 5 & 25.0 & 25.0 & 40.0 \\
\hline & Somewhat agree & 7 & 35.0 & 35.0 & 75.0 \\
\hline & Strongly agree & 5 & 25.0 & 25.0 & 100.0 \\
\hline & Total & 20 & 100.0 & 100.0 & \\
\hline
\end{tabular}

Table 19 shows that there is a strong consensus about a positive correlation between business performance and SCM (60\%), with 40 per cent disagreeing or being uncertain.

\section{RESULTS: CHI-SQUARE TEST}

\subsection{Hypothesis analysis using chi-square test for independence}

A chi-square test for independence compares two variables in a contingency table to see whether they are related [9]. In a more general sense, it tests to see whether distributions of categorical variables differ from each other. One way of applying this test is to define the null hypothesis and the alternate hypothesis for sets of data that are to be compared. The chi-square value for the sets of data is then calculated and compared with a critical value that is obtained from a chi-square table. If the chi-square value is less than the critical value, then there is no significant difference, and the null hypothesis can be rejected. The alternate hypothesis is then accepted.

Hypothesis to be tested: A positive correlation exists between SCM management practices and maintenance engineering performance (business performance).

Chi-square test for independence:

$\mathrm{H}_{0}$ : Management practices and business performance are independent

$\mathrm{H}_{1}$ : Management practices and business performance are not independent.

Chi-square statistic formula:

$$
\chi_{c}^{2}=\sum \frac{\left(O_{i}-E_{i}\right)^{2}}{E_{i}}
$$

where: Subscript ' $c$ ' $=$ degrees of freedom

$$
\begin{aligned}
& \mathrm{O}=\text { observed value } \\
& \mathrm{E}=\text { expected value }
\end{aligned}
$$

where the expected value $=(($ Row total $) \times($ column total $)) /$ sample total

Table 20: Labels

\begin{tabular}{|l|c|c|c|c|c|}
\hline Label & Strongly disagree & Disagree & Uncertain & Agree & Strongly agree \\
\hline Management & 41 & 38 & 53 & 37 & 31 \\
\hline Business performance & 31 & 37 & 60 & 25 & 27 \\
\hline Grand total & 72 & 75 & 113 & 62 & 58 \\
\hline
\end{tabular}


Table 21: Observed

\begin{tabular}{|l|c|c|c|c|}
\hline Label & Disagree & Uncertain & Agree & Total \\
\hline Management & 79 & 53 & 68 & 200 \\
\hline Business performance & 68 & 60 & 52 & 180 \\
\hline Grand total & 147 & 113 & 120 & 380 \\
\hline
\end{tabular}

Table 22: Expected

\begin{tabular}{|l|c|c|c|c|}
\hline Variable & Disagree & Uncertain & Agree & Total \\
\hline Management & 77.37 & 59.47 & 63.16 & 200 \\
\hline Business performance & 69.63 & 53.53 & 56.84 & 180 \\
\hline Grand total & 147 & 113 & 120 & 380 \\
\hline
\end{tabular}

Table 23: Observed minus Expected

\begin{tabular}{|c|c|c|c|c|}
\hline \multirow{4}{*}{ Observed (O) minus Expected (E) } & Variable & Disagree & Uncertain & Agree \\
\cline { 2 - 5 } & Management & 1.63 & -6.47 & 4.84 \\
\cline { 2 - 5 } & Business performance & -1.63 & 6.47 & -4.84 \\
\hline
\end{tabular}

Table 24: Observed minus Expected squared

\begin{tabular}{|c|l|c|c|c|}
\hline \multirow{4}{*}{ O-E squared } & Variable & Disagree & Uncertain & Agree \\
\cline { 2 - 5 } & Management & 2.662049861 & 41.9085873 & 23.44598338 \\
\cline { 2 - 5 } & Business performance & 2.662049861 & 41.9085873 & 23.44598338 \\
\hline
\end{tabular}

Table 25: (Observed minus Expected squared)/Expected

\begin{tabular}{|c|c|c|c|c|}
\hline \multirow{3}{*}{ O-E squared/E } & Variable & Disagree & Uncertain & Agree \\
\cline { 2 - 5 } & Management & 0.034407447 & 0.60530973 & 0.395833333 \\
\cline { 2 - 5 } & Business performance & 0.038230497 & 0.78295296 & 0.412475634 \\
\hline
\end{tabular}

\section{Chi-square $\quad 2.269209603$}

Number of degrees of freedom $=($ number of rows -1$)($ number of columns- 1$)=2$

Critical value of chi-square ( 2 degrees of freedom) at 0.05 using calculator $=5.99$

Interpretation

Since the chi-square is less than the critical value of chi-square, the null hypothesis is rejected. Thus the alternative hypothesis is accepted, showing that there is a relationship between management practices and business performance.

\section{CONCLUSIONS}

In this research, the following conclusions about the case study company were drawn:

- $\quad$ There is a supply chain management policy, but some managers are not conversant with, or aware of, the SCM policy.

- $\quad$ Non-committal responses on critical SCM matters show that there are inherent SCM challenges in the rail company.

- The research findings show that there are pockets of SCM excellence within the rail company. 
- $\quad$ The hypothesis testing done using the chi-square test shows that there is a positive relationship between SCM management practices and business performance - in this case, maintenance engineering performance.

\section{RECOMMENDATIONS}

As a result of the findings and conclusions, the following recommendations can be made:

- $\quad$ There is a need for training in SCM policy company-wide, starting with management teams, who are the drivers of successful policy implementation.

- $\quad$ Awareness campaign programmes should be used to disseminate the ideas of SCM goals and to promote SCM improvement throughout the organisation.

- $\quad$ There is a need to harness the internal SCM pockets of excellence revealed by the research, as it may be important to integrate these pockets of excellence to establish a company-wide SCM culture.

\section{REFERENCES}

[1] Donaldson Soberanis, I.E. 2010. An extended Bayesian network approach for analyzing supply chain disruptions, D.Phil. Dissertation, Graduate College of the University of lowa.

[2] Du Plooy-Cilliers, F., Davis, C. \& Bezuidenhout, R. 2014. Research matters. Claremont: Juta.

[3] Blanche, M.T., Durrheim, K. \& Painter, D. 2006. Research in practice: Applied methods for the social sciences. Cape Town: University of Cape Town Press.

[4] Nyathi, B. 2015. The advancement of train-set wheels management system based on ISO 55001 and the IRIS standard. M. Phil. Unpublished dissertation. Johannesburg: University of Johannesburg.

[5] Esposito, E. \& Passaro, R. 2009. Evolution of the supply chain in the Italian railway industry, International Journal of Supply Chain Management, Emerald Insight, 14(4), pp. 303-313.

[6] Sharma, S.C., Banga, T.R. \& Agarwal, N.K. 2000. Industrial engineering and management science, $10^{\text {th }}$ edition. Delhi: Khanna Publishers.

[7] Patton, Jr. J.D. 1994. Maintainability \& maintenance management, $3^{\text {rd }}$ edition, ISA Publishers, USA.

[8] Keen, P. 1998. Using condition monitoring systems to improve reliability of overhead electrified railway operations. London: AEA Technology Rail, the Institution of Electrical Engineers.

[9] Kraus-Liang, I. 2013. Chi-squared for dummies. Internet: https://prezi.com/brhlkobtljez/chi-squared-fordummies/, Accessed November 2017. 